\title{
Quantitative and Molecular Epidemiology of Bacterial Blight of Onion in Seed Production Fields
}

\author{
L. Humeau, P. Roumagnac, Y. Picard, I. Robène-Soustrade, F. Chiroleu, L. Gagnevin, and O. Pruvost
}

First, second, third, fourth, sixth, and seventh authors: research plant pathologists, and fifth author: statistician CIRAD, UMR Peuplements Végétaux et Bioagresseurs en Milieu Tropical CIRAD-Université de la Réunion, Pôle de Protection des Plantes, 7, chemin de l'Irat, 97410 Saint Pierre, La Réunion, France.

Current address of P. Roumagnac: Department of Molecular Biology, Max-Planck-Institut für Infektionsbiologie, Schumannstrasse 21/22, 10117 Berlin, Germany.

Accepted for publication 7 July 2006.

\begin{abstract}
Humeau, L., Roumagnac, P., Picard, Y., Robène-Soustrade, I., Chiroleu, F., Gagnevin, L., and Pruvost, O. 2006. Quantitative and molecular epidemiology of bacterial blight of onion in seed production fields. Phytopathology 96:1345-1354.

Onion, a biennial plant species, is threatened by the emerging, seedborne, and seed-transmitted Xanthomonas axonopodis pv. allii. Bacterial blight epidemics were monitored in seed production fields over two seasons. Temporal disease progress was different between the two seasons, with final incidence ranging from 0.04 to 0.06 in 2003 and from 0.44 to 0.61 in 2004 . The number of hours with temperatures above $24^{\circ} \mathrm{C}$ was the

of disease incidence data. The $\beta$-binomial distribution was superior to the binomial distribution for $97 \%$ of the examined data sets. Spatial dependency ranged from 5.9 to $15.2 \mathrm{~m}$, as determined by semivariance analysis. Based on amplified fragment length polymorphism (AFLP) analysis, it was concluded that plots predominantly were infected by the inoculated haplotype. A single other haplotype was identified by AFLP in all plots over the 2 years, and its detection in the field always followed winddriven rains. $X$. axonopodis pv. allii-contaminated seed were detected by semiselective isolation and a nested polymerase chain reaction assay at levels up to $0.05 \%$ when final disease incidence was 0.61 . Contaminated seed originated from both diseased and asymptomatic plants.
\end{abstract} best descriptor for predicting the number of days after inoculation for bacterial blight development on inoculated plants. Fitting the $\beta$-binomial distribution and binary power law analysis indicated aggregated patterns
Additional keywords: AFLP typing, quadrat size, seed contamination.
During the last three decades, bacterial blight of onion (Allium cepa $\mathrm{L}$.) (BBO) has been reported from many countries worldwide (43). BBO, caused by Xanthomonas axonopodis pv. allii, is a disease of several Allium spp., including onion, garlic (A. sativum L.), leek (A. porrum L.), and Welsh onion (A. fistulosum L.) (43). BBO initially was observed in Barbados in 1971 (36) and its causal agent was first characterized in Hawaii, where it appeared in 1975 (3). Recent studies have provided information about disease symptomatology $(36)$, yield losses $(35,49)$, inoculum sources $(13,14)$, pathogen classification (43), host range (43), and genetic diversity (43). In 2000, the discovery of $X$. axonopodis pv. allii's seedborne status $(13,14)$ raised questions about the biological mechanisms associated with seed contamination and the epidemiological significance of seedborne inoculum in bulb production fields.

The latter question was addressed by investigating the transmission of the pathogen from naturally contaminated seed to plants by using quantitative epidemiological tools (49). The temporal development of $\mathrm{BBO}$ in bulb production fields was best described by a nonlinear complementary log-log model. Spatial analyses of disease incidence were performed by combining measures of intracluster (the comparative fit to both the binomial and the $\beta$ binomial distributions and the binary form of Taylor's power law) and intercluster correlation (spatial autocorrelation and semivariance analysis) (45). The combination of these spatial analyses, which are becoming increasingly popular in plant pathology (16,

Corresponding author: O. Pruvost; E-mail address: olivier.pruvost@ cirad.fr

DOI: 10.1094/PHYTO-96-1345

(C) 2006 The American Phytopathological Society
$18,46,56)$, has shown that BBO spatial patterns were aggregated with ranges of spatial dependency of 1.1 to $2.2 \mathrm{~m}$, suggesting that seedborne inoculum of $X$. axonopodis pv. allii is associated with the development of epidemics and that it could be a source of primary inoculum for BBO (45). However, the lack of a powerful and discriminative method prevented the authors from determining the relative significance of seedborne inoculum and inoculum resulting from long distance dispersal (45).

The seedborne nature of $X$. axonopodis pv. allii, allowing for long-distance movement of the bacterium, combined with the lack of sensitive detection techniques have been hypothesized as factors possibly involved in the dissemination and emergence of $X$. axonopodis pv. allii during the past decades $(3,45)$. Once confined to a limited number of countries, BBO is now present in several areas of both the Old and New Worlds $(44,45)$, including major onion-producing countries (i.e., the United States, Japan, and Brazil) and significant yield losses (up to 50\%) have been reported $(35,49)$. Consequently, $X$. axonopodis pv. allii recently was included in the alert list of the European Plant Protection Organization (EPPO). Nevertheless, onion seed contamination rates from diseased fields have never been assessed and the mechanisms involved in seed contamination remain unknown. Therefore, there is a need to describe the epidemiology of BBO in seed production fields by integrating both quantitative and molecular analyses. Potentially, molecular epidemiological studies have the ability to clarify the biological significance of various inoculum sources in different environments $(13,54)$. The relatively large genetic diversity of $X$. axonopodis pv. allii $(12,15)$ may allow the identification of unique genotypes at a microgeographic scale.

Here, we present an experimental approach that combines temporal and spatial analyses of BBO and molecular epidemiology of 
its causal agent based on haplotype tracing at the field scale. In addition, we assess seed contamination from experimental plots by nested polymerase chain reaction (PCR) and semiselective isolation (44), and determine the relationship between disease status of leaves and inflorescences and seed contamination. Finally, we show that amplified fragment length polymorphism (AFLP) analysis is successful in identifying exogenous inoculum in epidemiological trials at a microgeographic scale.

\section{MATERIALS AND METHODS}

Experimental plots. BBO epidemics were monitored in two experimental plots (P1 and P2) during two successive onion cropping seasons (2003 and 2004). The experiments were performed at the Centre de Coopération Internationale en Recherche Agronomique pour le Développement (CIRAD) experimental station at Bassin Plat, Saint-Pierre (elevation $150 \mathrm{~m}$ above sea level, $21.310^{\circ} \mathrm{S}, 55.639^{\circ} \mathrm{E}$ ) and began in June 2003 and March 2004, respectively. Experimental plots were established with onion bulbs (A. cepa L. cv. Véronique) which were grown in a field where BBO was not observed for at least 2 years. Each experimental plot was 30 by $30 \mathrm{~m}$ and consisted of 60 rows of 120 onion plants oriented northwest to southeast. Onion bulbs were planted out $0.25 \mathrm{~m}$ apart within a row and $0.50 \mathrm{~m}$ apart across rows. Plots established the same year were separated by $30 \mathrm{~m}$ and were located on a line oriented at a right angle to the prevailing wind direction. Plots were surrounded by seven rows of maize to minimize inoculum moving between plots. The onion and maize plants were watered using drip irrigation at the beginning of the experiment. After inoculation, onion plots were watered with overhead irrigation using four sprinklers per plot. Each plot received $\approx 4.5 \mathrm{~mm}$ water per day (15 min twice a day starting at 5:00 a.m. and 6:00 p.m.). One month after planting, 20 onion plants per plot $(0.25 \%$ contamination rate) were inoculated with a bacterial suspension in 0.01 M sterile Sigma 7-9 buffer ( $\mathrm{pH} 7.2$ ) containing $\approx 10^{8} \mathrm{CFU} \mathrm{ml} \mathrm{m}^{-1}$ (optical density at $600 \mathrm{~nm}=0.05$ ) and prepared from an overnight culture on YPGA medium (yeast extract, $7 \mathrm{~g}$ liter ${ }^{-1}$; peptone, $7 \mathrm{~g} \mathrm{liter}^{-1}$; glucose, $7 \mathrm{~g} \mathrm{liter}^{-1}$; agar, $18 \mathrm{~g} \mathrm{liter}^{-1}$; $\mathrm{pH}$ 7.2) of strain LMG 16528 (BCCM/LMG Ghent University, Belgium). Plants were inoculated by swabbing the bacterial suspension on wounds created with a sterile needle. In all, four inoculations were performed on four distinct leaves of each inoculated plant. The coordinate position of the inoculated plants was obtained by computer-generated random sampling and the same positions for inoculated plants were used again in 2004.

Strain LMG 16528 was used for inoculation because its fingerprint obtained with the $\mathrm{SacI}+\mathrm{C} / \mathrm{Msp} \mathrm{I}+\mathrm{A}$ AFLP conditions revealed at least three fragments absent for all other strains and the absence of one fragment present for all other strains of $X$. axonopodis $\mathrm{pv}$. allii known to be present on the Mascarene archipelago. This AFLP haplotype, which has been very rarely detected in Réunion Island during the last decade, never was isolated in the vicinity of the experimental station. Pathogenicity of strain LMG 16528 previously was checked on onion (42) and no difference in aggressiveness was observed when compared with the other strains of $X$. axonopodis pv. allii isolated in the Mascarene archipelago (Y. Picard, D. Legrand, and O. Pruvost, unpublished data).

Minimum, maximum, and average temperature, rainfall, and humidity, plus wind speed and direction, were recorded hourly during the experiments using a Cimel CE407 weather station (Cimel Electronique, Paris). The relationship between weather data and the temporal progress of BBO (expressed as the derivative of disease incidence over time or as parameters derived from the nonlinear Gompertz model) was assessed by principal component analysis using R 2.0.1. R software is available online from the $\mathrm{R}$ foundation for statistical computing.

Disease assessment. The positions of missing plants were mapped 15 days after planting. A plant was considered missing when it was absent or when the leaves did not develop normally. There were 99 (1.38\%), $108(1.50 \%), 167$ (2.32\%), and 208 (2.89\%) missing plants in P1-2003, P2-2003, P1-2004, and P22004, respectively.

Disease assessments were performed over 4 months (from 8 July until 12 November 2003 and from 29 April until 3 September 2004). Rain occurred late on the inoculation day in 2003 (15 mm from 4:00 to 10:00 p.m.; maximum intensity $20 \mathrm{~mm} \mathrm{~h}^{-1}$ at 6:00 p.m. for a few minutes). Plots were inspected twice a week after inoculation to determine the date of appearance of disease symptoms. Water-soaked, chlorotic, or necrotic lesions on leaves were considered to be typical disease symptoms. Disease assessments were performed every 15 days after lesions had developed on inoculated plants. Inspections were delayed by a maximum of 5 days in the case of rain occurrence. Therefore, symptom development always was recorded on dry plants (to minimize dispersal of bacteria during disease assessments) and were recorded as presence or absence on each plant by visual assessment. All doubtful symptoms were assayed for the presence of $X$. axonopodis pv. allii by nondestructively swabbing lesions with $200 \mu \mathrm{l}$ of $0.01 \mathrm{M}$ sterile Sigma 7-9 buffer ( $\mathrm{pH} 7.2$ ) and streaking aliquots on NCTM1 semiselective medium $(44,45)$. Maps with locations of all symptomatic and asymptomatic plants were established as binary data for each $\mathrm{BBO}$ assessment date. In each disease focus, at least one lesion from each of three different onion leaves or floral stems were nondestructively sampled as explained above and cultures were stored at $-80^{\circ} \mathrm{C}$ on beads in cryovials (Microbank Prolab Diagnostics, Austin, TX) prior to AFLP typing. Pathogenicity of a subset of eight field isolates differing from the inoculated strain by AFLP was assessed as described previously (47).

Temporal analyses. Disease incidence was calculated for each plot and each assessment date as the proportion of diseased plants in the plot. Disease progress curves were fitted by various growth models using nonlinear logistic, probit, complementary log-log, Gompertz, and exponential models. Parameters were estimated for each plot using S-PLUS (version 6.1; Insightful Corporation, Seattle, WA). The appropriateness of each model was assessed by examination of the residual plots, correlation analysis of observed versus predicted values, and use of the Akaike criterion (10). For each plot, $r^{*}$ (disease incidence progress rate), $K$ (the maximum amount of disease, equivalent to the asymptote of the disease progress curve), and $x_{0.5 \mathrm{~K}}$ (the number of days after inoculation corresponding to $0.5 \mathrm{~K}$ ) were calculated. Asymptotic confidence intervals $(95 \%)$ were estimated for the selected model (21). The product $r^{*} K$, used as an overall (mean) measure of the absolute rate of disease increase, also was calculated (7).

Spatial analyses. Distribution analyses. Cluster sampling consisting of $N$ sampling units of $n$ individuals each was used to determine which distribution best described the data or to estimate parameters of the binary power law. When aggregation is present at some scale, changing the quadrat size can affect the degree of spatial dependence detected and can alter the interpretation of the spatial pattern (9). The Greig-Smith's method (19) modified by Ludwig (30) was used to determine the optimal quadrat size. Three quadrat sizes ( 2 by 4,4 by 8 , and 6 by 12 plants per quadrat corresponding to 900,225 , and 100 quadrats per plot, respectively) were chosen, because variance was high at these quadrat sizes in all experimental plots. The largest scale variance was observed for the 4-by-8 quadrat size.

For each plot, heterogeneity of disease incidence was evaluated by fitting the binomial and $\beta$-binomial distributions to the data (23) using the computer programs EGRET for Windows (version 2.0.31; Cytel Software Corporation, Cambridge, MA) and BBD (32). Fitting the $\beta$-binomial distribution involved estimating the probability $(p)$ that a plant is diseased by the mean disease incidence $(\hat{p})$, a second parameter $\theta$ that characterizes heterogeneity of $p$. The index of dispersion $(D)$ also was calculated for each data set. $D$ was expressed as the ratio between the observed vari- 
ance of the proportions and the expected value if the binomial distribution was appropriate (i.e., there was no overdispersion). A likelihood-ratio test (LRT) was used to determine whether the $\beta$-binomial distribution provided a better fit than the binomial distribution. Values of $D>1$ suggest aggregation because the observed variance of disease incidence is inflated above the expected binomial variance.

Binary power law analyses. The binary form of Taylor's power law (55) for disease incidence can be written as (22)

$$
V_{\mathrm{obs}}=A V_{\text {bin }}^{b}
$$

where $V_{\text {obs }}$ is the observed sample variance (described in equation $4), V_{\text {bin }}$ is the theoretical random variance, and $A$ and $b$ are coefficients estimated by regression analysis. For disease incidence data, the theoretical random variance $V_{\text {bin }}$ is estimated from the binomial variance for disease counts by

$$
V_{\text {bin }}=[\hat{p}(1-\hat{p}) / n]
$$

where $n$ is the number of plants per quadrat. Because the number of plants per quadrat was not constant, a mean value $\bar{n}$ for each plot was calculated as

$$
\bar{n}=\frac{n_{i}}{N}
$$

where $n_{i}$ is the number of plants in each quadrat, $i=1,2, \ldots$, and $N$, and $N$ is the total number of quadrats, depending on the selected quadrat size.

An approximation of the observed sample variance was calculated for each plot according to the formula of Cochran (8) for $n$ as

$$
V_{\mathrm{obs}}=\frac{\left[\sum n_{i}^{2}\left(y_{i}-\hat{p}\right)^{2}\right]}{\left[\bar{n}^{2}(N-1)\right]}
$$

where

$$
y_{i}=\frac{X_{i}}{n_{i}}, \hat{p}=\frac{\sum X_{i}}{\sum n_{i}}
$$

and $X_{i}$ is the number of diseased plants in quadrat $i$, with $i=$ $1,2, \ldots, N$. The power law model can then be written as

$$
\log \left(V_{\mathrm{obs}}\right)=\log (A)+b \log [\hat{p}(1-\hat{p}) / n]
$$

where $\log (A)$ and $b$ are the intercept and slope of a straight line, respectively. In equation 5 , a binomial distribution is indicated by $b=1$ and $A=1$. Aggregated disease patterns are suggested by $A>$ 1. In such a case, $b=1$ indicates that $\theta$ does not depend on $p$, whereas $b>1$ indicates that the $\beta$-binomial parameter $\theta$ depends on $p$. That is, the degree of aggregation changes with disease incidence. The binary power law was fitted with data derived from each experimental plot. Student $t$ tests were used to test equality of residual variance and regression slope between binomial line (i.e., observed variance $=$ theoretical binomial variance) and calculated regression line.

Geostatistical analyses. Semivariograms were produced by semivariance analysis. A parabolic shape of semivariograms indicates a strongly aggregated distribution. Parameters in the semivariograms are expressed as the localized discontinuity $\left(\mathrm{C}_{0}\right)$, the sill $\left(\mathrm{C}+\mathrm{C}_{0}\right)$, and the range of spatial dependency (A). The localized discontinuity, related to the $y$ intercept, is an indication of the amount of aggregation, where values closer to zero indicate stronger aggregation. The localized discontinuity also is indicative of the amount of random variation and measurement errors, and the proportion of the total variation that is below the sample scale. The sill is the point along the $y$ axis where the semivariance no longer increases. The range of spatial dependency is the minimum distance separating observations that are spatially independent. Samples separated by distances shorter than the range are considered to be spatially autocorrelated, whereas those separated by distances greater than the range are not.
Individual plants were assigned a temporal value calculated as the number of days a plant was infected relative to the total duration of the experiment. Thus, a plant weighted more if it became infected earlier rather than later in the epidemic. Semivariances were plotted against distance using GS+ software (version 5.32; Gamma design Software, Plainwell, MI) set for $0^{\circ}$ relative to the axis of the rows, with a tolerance of $\pm 180^{\circ}$ (omnidirectional analyses). Linear, linear with sill, exponential, spheric, and Gaussian transitional models were fitted to standardized semivariance by means of a nonlinear regression analysis using GS+ 5.32. Directional dissemination of the pathogen in the plots was analyzed by subsequent standardized semivariance analyses that were performed for $0^{\circ}, 45^{\circ}, 90^{\circ}$, and $135^{\circ}$ relative to the row, with an angle of $\pm 90^{\circ}$ to detect anisotropy.

Seed contamination. For infructescence harvest, each plot was divided into quadrats which were $15 \mathrm{~m}^{2}$ in size. In each quadrat, infructescences were collected in paper bags and harvested either as two samples (originating from diseased plants or originating from plants remaining symptomless throughout the experiment) or one sample (disease-free area in the plot or fully diseased). Onion plants in the experimental plots bore $3.75 \pm 1.54(n=244)$ and $3.47 \pm 1.29(n=300)$ inflorescences per plant in 2003 and 2004 , respectively. A total of 78, 76, 81, and 97 samples were obtained in P1-2003, P2-2003, P1-2004, and P2-2004, respectively. Infructescences were allowed to dry for 1 to 2 months before seed were hand picked from at least 20 infructescences per sample and preserved in sterile containers at $4^{\circ} \mathrm{C}$ for later bacteriological and molecular analysis.

For each sample, up to five subsamples containing $1 \mathrm{~g}$ of seed were soaked in $5 \mathrm{ml}$ of $0.01 \mathrm{M}$ sterile Sigma 7-9 buffer ( $\mathrm{pH} 7.2$ ) for $48 \mathrm{~h}$ at $4^{\circ} \mathrm{C}$. Macerates then were streaked on the semiselective medium NCTM1. Analyses and determinations of $X$. axonopodis pv. allii population sizes were performed as described previously (44). In addition, total bacterial genomic DNA was extracted from macerates by a quick alkaline DNA extraction method adapted from Audy et al. (4). Seed macerates were centrifuged at $10,000 \times g$ for $30 \mathrm{~min}$ and pellets were dissolved in $100 \mu \mathrm{l}$ of $0.5 \mathrm{~N} \mathrm{NaOH}$ with $0.5 \%$ polyvinylpyrrolidone (PVP). The lysate $(5 \mu \mathrm{l})$ was transferred to 1.5 -ml microfuge tubes containing $495 \mu \mathrm{l}$ of $20 \mathrm{mM}$ Tris-HCL, pH 8.0. One aliquot $(1 \mu \mathrm{l})$ was used per individual PCR assay. The first round of PCR was performed with primers PXaa1U (5'-GGCTCTAATACGACGTTGACGAT- $3^{\prime}$ ) and Pxaa1L (5'-AAATTCATGCGCGTTTTCAATAG-3'), which complement bases 197 to 219 and bases 871 to 893, respectively, of a sequence-characterized amplified region (SCAR) specific to $X$. axonopodis pv. allii strains (41). All $X$. axonopodis pv. allii genotypes identified so far in Réunion Island and the neighbor Mauritius Island, including LMG 16528, can be detected by PCR using this primer pair (41). The amplification program included denaturation at $94^{\circ} \mathrm{C}$ for $5 \mathrm{~min}$; 40 cycles consisting of denaturation at $95^{\circ} \mathrm{C}$ for $1 \mathrm{~min}$, annealing at $68^{\circ} \mathrm{C}$ for $1 \mathrm{~min}$, and extension at $72^{\circ} \mathrm{C}$ for $2 \mathrm{~min}$; and a final extension step at $72^{\circ} \mathrm{C}$ for $5 \mathrm{~min}$. The primers used in the second PCR round were NxaaU1 (5'-TTACGTCGCAAACAATCCAGATA-3') and NxaaL1 (5'-GGGCACCATTGACATTATCAGTT-3'), which complement bases 424 to 446 and 848 to 870 of the SCAR sequence, respectively. For the second round of PCR, $1 \mu \mathrm{l}$ from the first reaction was used as template and the amplification program consisted of denaturation at $94^{\circ} \mathrm{C}$ for $5 \mathrm{~min}$; followed by 30 cycles of $94^{\circ} \mathrm{C}$ for $30 \mathrm{~s}, 68^{\circ} \mathrm{C}$ for $30 \mathrm{~s}$, and $72^{\circ} \mathrm{C}$ for $40 \mathrm{~s}$; and a final extension at $72^{\circ} \mathrm{C}$ for $5 \mathrm{~min}$. PCRs were performed in $25-\mu \mathrm{l}$ reaction mixtures containing $3 \mathrm{mM} \mathrm{MgCl}_{2}, 100 \mu \mathrm{M}$ each dNTP, $0.2 \mu \mathrm{M}$ each primer (PXaa1U/Pxaa1L or NxaaU1/NxaaL1), $1 \mu \mathrm{l}$ of template DNA, and 1.25 U of Taq polymerase Goldstar Red (Eurogentec, Seraing, Belgium) in $75 \mathrm{mM}$ Tris- $\mathrm{HCl}, 20 \mathrm{mM}$ $\left(\mathrm{NH}_{4}\right)_{2} \mathrm{SO}_{4}$, and $0.01 \%$ Tween 20 buffer $(\mathrm{pH} 8.8)$. PCR reaction products were separated by electrophoresis in $1 \%$ Seakem LE agarose (FMC Bioproducts, Rockland, ME), stained with ethidium 
bromide, and visualized with UV light. All the macerates were analyzed at least twice by nested PCR. Because nested PCR is known to sometimes produce false positives, only samples from which the expected DNA fragment was detected twice were scored as positive. Nested PCR also was used to confirm the identity of xanthomonad-like colonies recovered from seed macerates on the semiselective medium. The procedure was identical to that described above except that, in this case, templates consisted of $1 \mu \mathrm{l}$ of suspensions prepared in water from pure bacterial cultures (one single colony in $1 \mathrm{ml}$ of deionized water, boiled for $1 \mathrm{~min}$ ).

Seed contamination rates derived from plate counts and from N-PCR analyses were calculated as described by Masmoudi et al. (33). Pathogenicity of a subset of six seed isolates was assessed as described previously (47). The seed contamination rates in samples collected from diseased and asymptomatic plants were compared by an exact binomial signed rank test using $\mathrm{R}$ 2.0.1.

AFLP analysis. Strains preserved at $-80^{\circ} \mathrm{C}$ were streaked on YPGA plates to check for purity. Single colonies were subcultured on YPGA plates for $24 \mathrm{~h}$ at $28^{\circ} \mathrm{C}$. These subcultures were used to inoculate $4 \mathrm{ml}$ of YP broth (yeast extract, $7 \mathrm{~g} \mathrm{liter}^{-1}$; peptone, $7 \mathrm{~g} \mathrm{liter}^{-1}$; $\mathrm{pH}$ 7.2) tubes, which were incubated at $28^{\circ} \mathrm{C}$ under agitation for 16 to $18 \mathrm{~h}$. These suspensions were used for DNA extraction using the DNeasy tissue kit (Qiagen, Courtaboeuf, France) following the manufacturer's instructions. DNA concentrations were estimated by fluorometry (TKO 100 Fluorometer, Hoefer, San Francisco). The AFLP experiments were performed in 96-well plates in a GeneAmp PCR system 9700 thermocycler (Applied Biosystems, Courtaboeuf, France).

Digestions were carried out in a $25-\mu \mathrm{l}$ volume for $1 \mathrm{~h}$ at $37^{\circ} \mathrm{C}$ and contained $100 \mathrm{ng}$ of bacterial genomic DNA, $10 \mathrm{U}$ of SacI, $2 \mathrm{U}$ of MspI (New England Biolabs/Ozyme, Saint Quentin en Yvelines, France), and $1 \times$ bovine serum albumin in $1 \times$ reaction buffer NEB 1. Then, $2.5 \mu$ of the digested products was added to $22.5 \mu \mathrm{l}$ of a ligation mix containing $2 \mu \mathrm{M}$ MspI adaptor, $0.2 \mu \mathrm{M}$ SacI adaptor, and $2 \mathrm{U}$ of T4 DNA ligase (New England Biolabs/Ozyme, Saint Quentin en Yvelines, France) in 1× T4 DNA ligation buffer. Adapters were prepared by mixing the two oligonucleotides (5'-GACGATGAGTCCTGAG-3' and 5'-CGCTCAGGACTCATC-3' for $M s p$ I adaptor and 5'-CTCGTAGACTGCGTACAAGCT-3' and 5'-TGTACGCAGTCTACG-3' for SacI adaptor) (Applied Biosystems) at equal concentrations for $5 \mathrm{~min}$ at $95^{\circ} \mathrm{C}$ and allowing to cool to ambient temperature for $10 \mathrm{~min}$. Ligations were performed for $3 \mathrm{~h}$ at $37^{\circ} \mathrm{C}$ before enzyme inactivation at $65^{\circ} \mathrm{C}$ for $10 \mathrm{~min}$. Ligation products were diluted 10 -fold with high-performance liquid chromatography (HPLC)-grade water before preselective PCR. The reactions were done in $15 \mu \mathrm{l}$

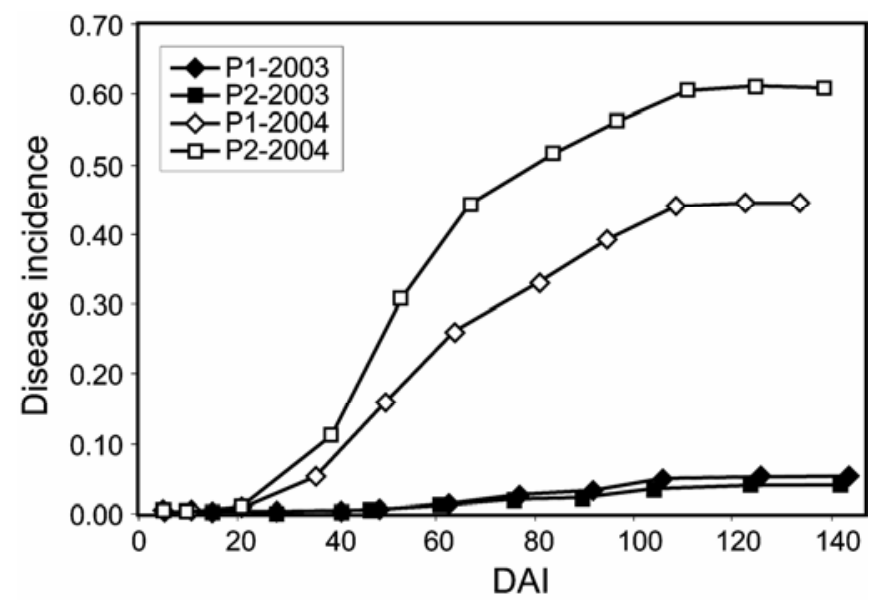

Fig. 1. Temporal disease progress of bacterial blight of onion in four experimental plots established with $0.25 \%$ Xanthomonas axonopodis pv. alliicontaminated plants during two onion cropping seasons in La Réunion Island. DAI = days after inoculation. and contained $5 \mu \mathrm{l}$ of diluted ligation product, $2.5 \mathrm{mM} \mathrm{MgCl}_{2}$, $0.23 \mu \mathrm{M}$ each $\mathrm{MspI}$ and SacI primer (5'-GATGAGTCCTGAGCGG-3' and 5'-TAGACTGCGTACAAGCTC-3', respectively), $0.45 \mathrm{mM}$ each dNTP (New England Biolabs/Ozyme, Saint Quentin en Yvelines, France), and 0.5 U of Taq DNA polymerase (Goldstar Red; Eurogentec, Seraing, Belgium) in 1× Goldstar buffer. The following PCR conditions were used: initial extension to ligate the second strand of the adaptors at $72^{\circ} \mathrm{C}$ for $2 \mathrm{~min}$; then a denaturation step at $92^{\circ} \mathrm{C}$ for $2 \mathrm{~min}$; followed by 25 cycles at $94^{\circ} \mathrm{C}$ for $30 \mathrm{~s}, 56^{\circ} \mathrm{C}$ for $30 \mathrm{~s}$, and $72^{\circ} \mathrm{C}$ for $2 \mathrm{~min}$; and a final extension step at $72^{\circ} \mathrm{C}$ for $10 \mathrm{~min}$. PCR products were diluted 10-fold with HPLC-grade water before selective amplification. The selective amplifications using the unlabeled $M s p \mathrm{I}+\mathrm{A}$ primer and the 5'-VIC-labeled SacI+C primer were performed in the same conditions as the preselective PCR, except that the $\mathrm{Sac} \mathrm{I}+\mathrm{C}$ primer concentration was $0.12 \mu \mathrm{M}$. This selective primer pair was selected based on a preliminary AFLP analysis (data not shown) using 12 primer pair combinations and 25 strains of $X$. axonopodis pv. allii covering the known genetic diversity of the pathogen in the Mascarene archipelago (Réunion and the neighboring Mauritius and Rodrigues islands). The following PCR conditions were used: initial denaturation at $94^{\circ} \mathrm{C}$ for $2 \mathrm{~min}$; followed by 37 cycles at $94^{\circ} \mathrm{C}$ for $30 \mathrm{~s}$, annealing for $30 \mathrm{~s}$ at $65^{\circ} \mathrm{C}$ for the first cycle, then decreased by $0.7^{\circ} \mathrm{C}$ per cycle for the next 12 cycles, and $56^{\circ} \mathrm{C}$ for the last 24 cycles; and extension at $72^{\circ} \mathrm{C}$ for $2 \mathrm{~min}$, with a final extension step at $72^{\circ} \mathrm{C}$ for $10 \mathrm{~min}$. Samples then were prepared for capillary electrophoresis by adding $1 \mu$ of the final PCR product to $18.7 \mu$ of formamide and $0.3 \mu$ of LIZ500 DNA ladder (Applied Biosystems) as an internal standard. The mixture then was denatured for $5 \mathrm{~min}$ at $95^{\circ} \mathrm{C}$ and placed on ice for at least 5 min. Electrophoresis was performed in an ABI PRISM-3100 Genetic Analyzer (Applied Biosystems) using performance-optimized polymer POP-4 at $15,000 \mathrm{~V}$ for $\approx 20 \mathrm{~min}$ at $60^{\circ} \mathrm{C}$, with an initial injection of $44 \mathrm{~s}$. The AFLP fingerprints were analyzed visually using Genescan software 3.7 (Applied Biosystems).

In all, 378 field isolates (all originating from single colonies) from lesions on leaves or floral stems were analyzed by AFLP. Of these, 74, 46, 125, and 133 isolates originated from plots P12003, P2-2003, P1-2004, and P2-2004, respectively. Recovery of bacterial isolates was done at each disease assessment date. All identified disease foci were sampled in each experimental plot and at least five isolates were obtained from all disease foci. Forty-one isolates recovered from 31 seed macerates also were analyzed. In order to accurately type the field isolates and test the reproducibility of the AFLP technique, DNAs from strains CFBP 6366 (INRA Angers, France), CFBP 6369 (syn. LMG 21894), and LMG 16528 were used as controls in each experiment $(n=37)$. Field strains identified by AFLP as different to the inoculated strain (LMG 16528) were grown again on YPGA from the stock and ADN was re-extracted to confirm the AFLP results from independent DNA extractions.

\section{RESULTS}

Disease assessment and climatic data. The first symptoms appeared between 24 and 37 days after inoculation (DAI) on the inoculated plants in 2003 and only 5 to 10 DAI on the inoculated plants in 2004. The first symptoms on noninoculated plants appeared 41 and 21 DAI in 2003 and 2004, respectively. A rapid dieback was observed on inoculated leaves once lesions had developed. These initial symptoms were detected on both inoculated and noninoculated leaves. Maximum observed disease incidences were $0.051,0.039,0.442$, and 0.609 in P1-2003, P2-2003, P1-2004, and P2-2004, respectively (Fig. 1). The examination of weather data revealed differences in mean daily temperatures during the 2003 and 2004 outbreaks. For example, mean daily temperatures from the date of inoculation until the beginning of a decrease in disease progress rates (60 days) were lower by $1.6^{\circ} \mathrm{C}$ in 2003 
$\left(19.2 \pm 1.0\right.$ versus $\left.20.8 \pm 1.4^{\circ} \mathrm{C}\right)$. As suggested by principal component analysis, other recorded climatic variables or variable combinations were not markedly different among experiments (data not shown). Total rainfall from the date of inoculation until the beginning of a decrease in disease progress rates (60 days) was not markedly different (200 and $179 \mathrm{~mm}$ in 2003 and 2004, respectively). For the same period, a rain-wind index expressed as the sum of rain (millimeters)-wind (meters per second) products calculated from hourly data was higher in 2004 (312.2 versus 250.4).

The occurrence of BBO lesions on floral stems was associated with an increase by $38 \%$ (unpaired $t$ test, $t=1.84, P=0.033$ ) of infructescence lodging.
Temporal analysis. All fitted models provided a satisfactory description of the disease progress curve for each plot. The probit and Gompertz models were most appropriate for the 2003 and 2004 data sets, respectively (Table 1). The amount of time after inoculation necessary to reach $50 \%$ of the maximum disease incidence ranged from 79 to 84 days in 2003 , depending on the plot and the model used, and from 54 to 61 days in 2004.

Spatial analysis. Distribution analyses. Maximum likelihood estimates of $\theta$ converged for 31 of 38 disease assessments (Table 2 ). The associated likelihood ratio statistic indicated that the $\beta$-binomial distribution provided a better fit to the data than the binomial distribution for $97 \%$ of the data sets (Table 2).

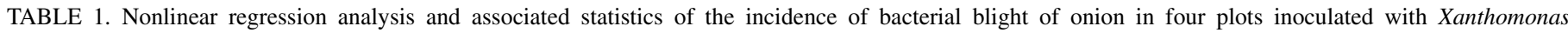
axonopodis pv. allii during two successive years

\begin{tabular}{|c|c|c|c|c|c|c|c|c|}
\hline Plot & Model $^{\mathrm{a}}$ & Rate $\left(r^{*}\right)$ & $\mathrm{SE}$ of $r^{*}$ & $\begin{array}{l}\text { Maximum amount } \\
\text { of disease }(K)\end{array}$ & $\mathrm{SE}^{\mathrm{b}}$ of $K$ & $\begin{array}{l}\text { Absolute rate } \\
\left(r^{*} K\right)\end{array}$ & $R^{2 \mathrm{c}}$ & $\begin{array}{c}\text { No. of days } \\
\text { incidence } 0.5 K^{\mathrm{d}}\end{array}$ \\
\hline \multirow[t]{2}{*}{ P1-2003 } & Probit & 0.0422 & 0.0040 & 0.0524 & 0.0012 & 0.0022 & 0.990 & $80.6(77.5-83.7)$ \\
\hline & Gompertz & 0.0397 & 0.0067 & 0.0572 & 0.0038 & 0.0023 & 0.988 & $82.9(75.2-90.6)$ \\
\hline \multirow[t]{2}{*}{ P2-2003 } & Probit & 0.0378 & 0.0039 & 0.0398 & 0.0011 & 0.0015 & 0.986 & $79.3(75.5-83.1)$ \\
\hline & Gompertz & 0.0335 & 0.0061 & 0.0450 & 0.0039 & 0.0015 & 0.986 & 83.7 (72.9-94.4) \\
\hline \multirow[t]{2}{*}{ P1-2004 } & Probit & 0.0411 & 0.0033 & 0.4400 & 0.0093 & 0.0181 & 0.996 & $61.3(58.3-64.2)$ \\
\hline & Gompertz & 0.0438 & 0.0028 & 0.4614 & 0.0086 & 0.0202 & 0.998 & $61.3(58.9-63.6)$ \\
\hline \multirow[t]{2}{*}{ P2-2004 } & Probit & 0.0503 & 0.0005 & 0.5938 & 0.0119 & 0.0299 & 0.994 & $54.6(51.8-57.4)$ \\
\hline & Gompertz & 0.0564 & 0.0036 & 0.6110 & 0.0080 & 0.0345 & 0.998 & $54.1(52.5-55.7)$ \\
\hline
\end{tabular}

a Model indicated in italics was most suitable, based on Akaike information criterion (AIC).

b $\mathrm{SE}=$ standard error.

c Adjusted coefficient of multiple determination.

${ }^{\mathrm{d}}$ Number of days after inoculation for an incidence of $0.5 \mathrm{~K}$. Values in brackets are asymptotic confidence interval bounds ( $95 \%$ ).

TABLE 2. Estimated $\beta$-binomial aggregation parameter at each disease assessment in four plots for a 4-by-8 quadrat size

\begin{tabular}{|c|c|c|c|c|c|c|c|}
\hline Plot assessment $^{\mathrm{a}}$ & $\begin{array}{l}\text { Days after } \\
\text { inoculation }\end{array}$ & Incidence $(p)$ & $\begin{array}{c}\text { Index of } \\
\text { dispersion }(D)\end{array}$ & $p(\mathrm{MLE})^{\mathrm{b}}$ & $\theta$ (standard error) & $\begin{array}{c}\text { Likelihood ratio } \\
\text { statistic }\end{array}$ & $P$ value ${ }^{c}$ \\
\hline P1-2003-2 & 28 & 0.001 & 1.18 & 0.0013 & $0.0068(0.00753)$ & 1.9 & 0.082 \\
\hline P1-2003-3 & 41 & 0.002 & 1.25 & 0.0018 & $0.0097(0.00746)$ & 3.8 & 0.025 \\
\hline P1-2003-4 & 49 & 0.005 & 3.23 & 0.0046 & $0.0818(0.02953)$ & 71.9 & $<0.001$ \\
\hline P1-2003-5 & 63 & 0.012 & 5.85 & 0.0120 & $0.2198(0.05651)$ & 252 & $<0.001$ \\
\hline P1-2003-6 & 77 & 0.025 & 6.86 & 0.0245 & $0.3148(0.06303)$ & 486 & $<0.001$ \\
\hline P1-2003-7 & 92 & 0.030 & 6.97 & 0.0295 & $0.3172(0.05897)$ & 543 & $<0.001$ \\
\hline P1-2003-8 & 106 & 0.048 & 6.76 & 0.0463 & $0.3049(0.04747)$ & 650 & $<0.001$ \\
\hline P1-2003-9 & 126 & 0.052 & 7.05 & 0.0501 & $0.3224(0.04887)$ & 712 & $<0.001$ \\
\hline P2-2003-2 & 28 & 0.001 & 0.97 & 0.0006 & $\ldots$ & $\ldots$ & $\ldots$ \\
\hline P2-2003-3 & 41 & 0.001 & 0.96 & 0.0010 & $\ldots$ & $\ldots$ & $\ldots$ \\
\hline P2-2003-4 & 47 & 0.005 & 3.53 & 0.0046 & $0.1080(0.03951)$ & 87.4 & $<0.001$ \\
\hline P2-2003-5 & 61 & 0.012 & 7.99 & 0.0118 & $0.2766(0.07554)$ & 309 & $<0.001$ \\
\hline P2-2003-6 & 76 & 0.019 & 9.51 & 0.0187 & $0.3927(0.09222)$ & 509 & $<0.001$ \\
\hline P2-2003-7 & 90 & 0.022 & 9.75 & 0.0214 & $0.3877(0.08831)$ & 547 & $<0.001$ \\
\hline P2-2003-8 & 104 & 0.034 & 9.08 & 0.0334 & $0.3975(0.07130)$ & 694 & $<0.001$ \\
\hline P2-2003-9 & 124 & 0.039 & 9.99 & 0.0379 & $0.4723(0.08430)$ & 832 & $<0.001$ \\
\hline P1-2004-1 & 5 & 0.002 & 1.31 & 0.0023 & $\ldots$ & $\ldots$ & $\ldots$ \\
\hline P1-2004-2 & 11 & 0.003 & 1.21 & 0.0028 & $0.0084(0.00611)$ & 3.5 & 0.003 \\
\hline P1-2004-3 & 21 & 0.009 & 3.60 & 0.0070 & $0.1550(0.06150)$ & 153 & $<0.001$ \\
\hline P1-2004-4 & 36 & 0.050 & 12.06 & 0.0459 & $0.6962(0.12143)$ & 1,185 & $<0.001$ \\
\hline P1-2004-5 & 50 & 0.157 & 14.91 & 0.1561 & $0.9331(0.10793)$ & 2,441 & $<0.001$ \\
\hline P1-2004-6 & 64 & 0.259 & 13.38 & 0.2474 & $0.8257(0.08359)$ & 2,613 & $<0.001$ \\
\hline P1-2004-7 & 81 & 0.330 & 13.44 & 0.3162 & $0.8181(0.07941)$ & 2,759 & $<0.001$ \\
\hline P1-2004-8 & 95 & 0.390 & 13.42 & 0.3664 & $0.8182(0.07781)$ & 2,834 & $<0.001$ \\
\hline P1-2004-9 & 109 & 0.437 & 13.89 & 0.4057 & $0.8730(0.08219)$ & 3,005 & $<0.001$ \\
\hline P1-2004-10 & 127 & 0.442 & 14.18 & 0.4098 & $0.8950(0.08402)$ & 3,086 & $<0.001$ \\
\hline P2-2004-1 & 5 & 0.003 & 0.95 & 0.0023 & $\ldots$ & $\ldots$ & $\ldots$ \\
\hline P2-2004-2 & 10 & 0.003 & 0.92 & 0.0029 & $\ldots$ & $\ldots$ & $\ldots$ \\
\hline P2-2004-3 & 21 & 0.007 & 2.82 & 0.0085 & $0.0971(0.02768)$ & 102 & $<0.001$ \\
\hline P2-2004-4 & 39 & 0.111 & 13.36 & 0.1047 & $0.7811(0.10044)$ & 1,916 & $<0.001$ \\
\hline P2-2004-5 & 53 & 0.308 & 16.67 & 0.2887 & $1.1760(0.11698)$ & 3,616 & $<0.001$ \\
\hline P2-2004-6 & 67 & 0.443 & 15.00 & 0.4165 & $0.9259(0.08429)$ & 3,293 & $<0.001$ \\
\hline P2-2004-7 & 84 & 0.515 & 15.20 & 0.4816 & $0.9045(0.08193)$ & 3,307 & $<0.001$ \\
\hline P2-2004-8 & 97 & 0.563 & 15.41 & 0.5270 & $0.9057(0.08131)$ & 3,315 & $<0.001$ \\
\hline P2-2004-9 & 111 & 0.606 & 15.95 & 0.5687 & $0.9551(0.08583)$ & 3,400 & $<0.001$ \\
\hline P2-2004-10 & 123 & 0.609 & 16.10 & 0.5724 & $0.9738(0.08778)$ & 3,437 & $<0.001$ \\
\hline
\end{tabular}

${ }^{a}$ Expressed as plot number-year-assessment number.

${ }^{\mathrm{b}} P$ values associated with the maximum likelihood estimation (MLE) procedure used to obtain parameter estimates.

c $P$ value is calculated by testing the square root of the likelihood ratio statistic as a standardized normal deviate. 
The index of dispersion $(D)$ was $>>1$, except at early stages of epidemics (i.e., disease incidence $\leq 0.003$ ) and increased with increasing quadrat size (data not shown) for all the plots and all the date assessments, whereas $\theta$ decreased with increasing quadrat size.

Binary power law analyses. The binary power law provided a good description of the relationship between $\log \left(V_{\text {obs }}\right)$ and $\log \left(V_{\text {bin }}\right)$ with an $R^{2}$ value of 0.99 for each quadrat size and plot

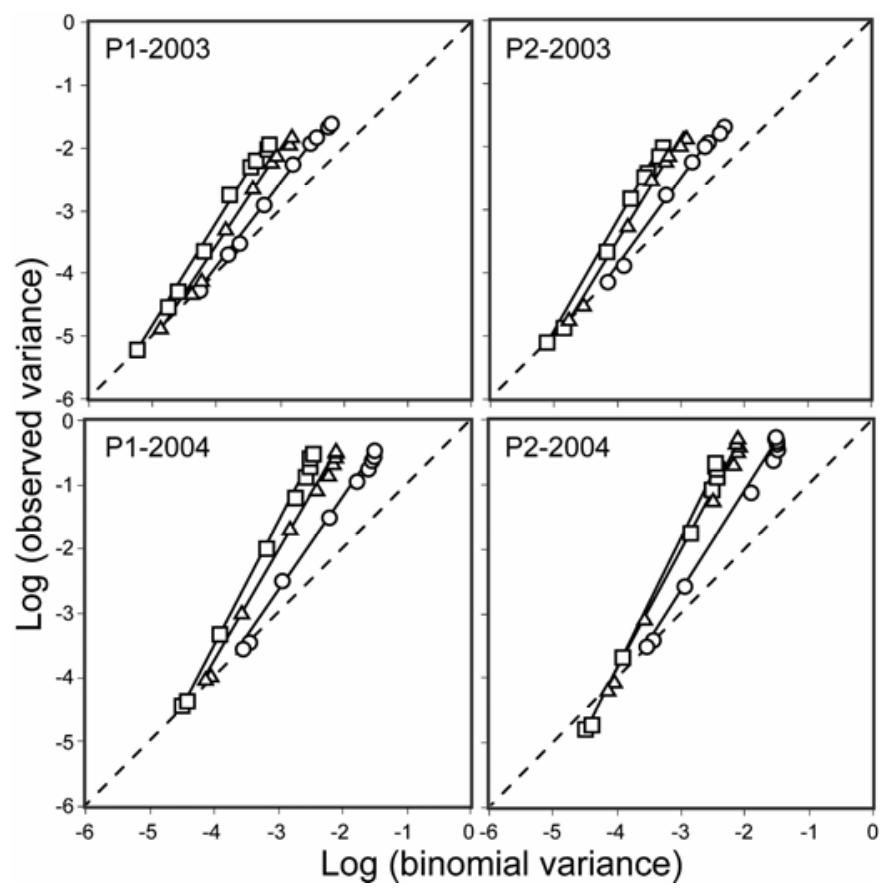

Fig. 2. Relationship between the logarithm of the observed variance and the logarithm of the binomial variance of disease incidence in four experimental onion seed production plots inoculated with Xanthomonas axonopodis pv. allii during two cropping seasons in La Réunion Island. Three quadrat sizes are presented ( $O=2$ by 4 plants, $\Delta=4$ by 8 plants, and $\square=6$ by 12 plants). The broken line represents the binomial (random) line, where the observed variance $=$ theoretical binomial variance.
(Fig. 2; Table 3). The slope $b$ and intercept $\log (A)$ values were $>1$ ( $t$ tests, $P<0.00001$ ) (Table 3 ), indicating that the degree of aggregation changed with $p$ for all the plots and all the quadrat sizes.

Geostatistical analysis. The shape of the semivariograms indicated aggregated disease patterns. All semivariograms were best fitted by the exponential model (Table 4). The localized discontinuity values $\left(\mathrm{C}_{0}\right)$ ranged from 0.300 to 0.356 . The range of spatial dependency ranged from 5.9 to $15.2 \mathrm{~m}$, indicating extensive aggregation over distance, which was maintained through time. The greatest range of spatial dependency $(15.2 \mathrm{~m})$ was recorded in plot P2-2004, suggesting coalescence of disease foci over time.

Slight anisotropy was detected, as indicated by little differences between major $\left(\mathrm{A}_{1}\right)$ and minor $\left(\mathrm{A}_{2}\right)$ range parameters calculated from anisotropic models (Table 4 ). This result was confirmed by an apparent directional dissemination in the prevailing wind direction, which appeared and maintained over time in the plots (data not shown).

Alternative inoculum. No variation of the AFLP patterns of the three control strains was observed in the 37 control runs. Based on AFLP analysis, most strains of $X$. axonopodis pv. allii isolated from leaf or floral stem lesions in the four experimental plots had fingerprints identical to that of the inoculated LMG 16528 strain. A single haplotype different from strain LMG 16528 also was detected in both 2003 and 2004 (Table 5). With the selective primer pair used in this study, this haplotype could not be distinguished from strain CFBP 6369, but differed by eight markers from strain CFBP 6366. This haplotype first was detected on 28 August 2003 and 14 June 2004. The CFBP 6369-like haplotype was present in two to five foci per plot (Table 5). Based on the overall study, we identified a total of 12 foci in which this haplotype was present. Four foci were situated at the edge of the plots. All CFBP 6369-like field isolates that were submitted to pathogenicity tests were virulent on onion cv. red creole.

Seed contamination. In 2004, numerous typical BBO lesions were observed on flower stems of all inoculated plants, leading to inflorescence dieback and lodging. As a consequence, no infructescence was harvested from inoculated plants for seed analysis. In 2003, only a few flower stem lesions were recorded on inoculated plants and harvest of infructescences was possible from 27 of 40 inoculated plants.

TABLE 3. Parameters describing the relationship between the logarithm of the observed variance and the logarithm of the binomial variance of disease incidence in four experimental plots for three quadrat sizes

\begin{tabular}{|c|c|c|c|c|c|c|c|c|c|c|c|c|}
\hline \multirow[b]{3}{*}{ Plots } & \multicolumn{12}{|c|}{ Quadrat size $^{\mathrm{a}}$} \\
\hline & \multicolumn{4}{|c|}{2 by 4} & \multicolumn{4}{|c|}{4 by 8} & \multicolumn{4}{|c|}{6 by 12} \\
\hline & $\log (A)$ & $b$ & $R^{2}$ & $t^{\mathrm{b}}$ & $\log (A)$ & $b$ & $R^{2}$ & $t^{\mathrm{b}}$ & $\log (A)$ & $b$ & $R^{2}$ & $t^{\mathrm{b}}$ \\
\hline $\mathrm{P} 2-2003 n=9$ & $1.380(0.036)$ & $1.574(0.115)$ & 0.99 & $15.0^{* * *}$ & $1.639(0.041)$ & $2.999(0.155)$ & 0.99 & $22.2^{* * *}$ & $1.731(0.034)$ & $3.655(0.141)$ & 0.99 & $30.3^{* *}$ \\
\hline $\mathrm{P} 1-2004 n=10$ & $1.469(0.029)$ & $1.685(0.067)$ & 0.99 & $22.6^{* * *}$ & $1.709(0.026)$ & $3.033(0.074)$ & 0.99 & $38.9^{* * * *}$ & $1.913(0.027)$ & $4.084(0.088)$ & 0.99 & $47.3^{ \pm s}$ \\
\hline $\mathrm{P} 2-2004 n=10$ & $1.556(0.040)$ & $1.945(0.090)$ & 0.99 & $19.6^{* * *}$ & $1.864(0.042)$ & $3.502(0.117)$ & 0.99 & $29.4^{* * *}$ & $2.004(0.049)$ & $4.122(0.155)$ & 0.99 & $28.8^{* *}$ \\
\hline
\end{tabular}

a Values in parentheses are standard errors.

b Values of Student $t$ test $(t)$ for the equality of regression slope between binomial line and calculated regression line; ${ }^{* * *}=P<0.00001$.

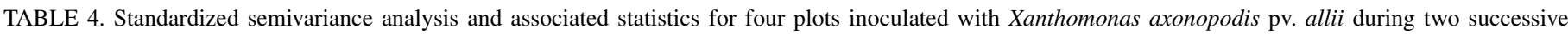
years

\begin{tabular}{|c|c|c|c|c|c|c|c|c|}
\hline \multirow[b]{2}{*}{ Plot } & \multirow[b]{2}{*}{ Model } & \multirow[b]{2}{*}{$R^{2}$} & \multicolumn{2}{|c|}{ Isotropic analysis } & \multirow[b]{2}{*}{$A_{0}(A)^{c}$} & \multicolumn{3}{|c|}{ Anisotropic analysis } \\
\hline & & & Discontinuity $\left(\mathrm{C}_{0}\right)^{\mathrm{a}}$ & $\operatorname{Sill}\left(\mathrm{C}+\mathrm{C}_{0}\right)^{\mathrm{b}}$ & & $\mathrm{A}_{1}$ & $\mathrm{~A}_{2}$ & $R^{2}$ \\
\hline P1-2003 & Exponential & 0.970 & 0.300 & 0.866 & $1.98(5.94)$ & 1.345 & 1.245 & 0.945 \\
\hline P2-2003 & Exponential & 0.953 & 0.356 & 1.329 & $2.38(7.14)$ & 2.078 & 1.977 & 0.951 \\
\hline P1-2004 & Exponential & 0.996 & 0.334 & 0.994 & $2.83(8.49)$ & 1.907 & 1.808 & 0.966 \\
\hline P2-2004 & Exponential & 0.962 & 0.343 & 1.010 & $5.08(15.24)$ & 16.63 & 16.48 & 0.933 \\
\hline
\end{tabular}

${ }^{a}$ Localized discontinuity is the y intercept and indicates the level of aggregation smaller than the scale of observation or measurement error.

b Sill is the $y$ axis point corresponding to the model asymptote.

${ }^{c}$ Range of spatial dependency $(A)$ is the distance over which spatial dependence is apparent $\left(A=3 \times A_{0}\right.$ in the case of the exponential model). 
$X$. axonopodis pv. allii was not detected in seed macerates from samples collected in 2003, whatever the technique used (nested PCR and semiselective isolation), even from seed collected on inoculated plants (Table 6). In contrast, X. axonopodis pv. allii was detected using both techniques from samples collected in 2004. Contaminated seeds were detected from both diseased and symptomless plants, although contaminated seed from symptomless plants were recorded more often from infructescences harvested in diseased quadrats (Table 6). Based on binomial signed rank tests, rates of seed contamination in lots originating from diseased plants were not different $(P>0.05)$ from those obtained for symptomless plants from diseased quadrats. $X$. axonopodis pv. allii recovered from seed-contaminated samples on NCTM1 medium $(n=32)$ all had fingerprints identical to that of LMG 16528. All isolates submitted to pathogenicity tests were virulent on onion cv. red creole. The CFBP 6369-like haplotype detected in experimental plots from leaf and flower stem lesions was not detected from seed.

\section{DISCUSSION}

The worldwide emergence of BBO may be due, to some extent, to the seedborne status of the causal agent, $X$. axonopodis pv. allii (44) and the increase of international trade and human travel, which has intensified international movement of pathogens in propagation material. In a previous article (45), we demonstrated that seedborne inoculum associated with naturally contaminated seed was likely to be the primary source of inoculum of outbreaks in a tropical environment. Strongly aggregated disease patterns expanded from a small number of primary foci, whose number was comparable with the seed contamination rate of the seed lot used. At a later stage of epidemics, it was noted that exogenous inoculum also could have accounted for disease increase (45). The present work was undertaken in order to describe the temporal and spatial progress of BBO in experimental seed production fields and evaluate the relationship between BBO status and seed contamination. Experimental plots were established in an area with no commercial onion crops and were inoculated with a rare bacterial haplotype that has a unique AFLP fingerprint and has never been recorded at the experimental site or in its vicinity, so that occurrence of exogenous inoculum in the experimental plots could be quantified by AFLP analysis.

The epidemic progress in seed production plots generally was similar to that described previously in bulb production plots (45) in terms of incidence progress curves and aggregation patterns. In plots of onion seed crops, the Gompertz model was the most appropriate model over the 2 years, whereas the complementary $\log$ - $\log$ model was superior for describing the temporal progress of BBO in bulb production plots (45). Spatial analyses indicated that aggregation was detected in all plots for all assessments and for all quadrat sizes. For nearly all plot-disease assessment date combinations, the $\beta$-binomial distribution provided a better fit to observed data than the binomial distribution (Table 2). Infected plants influenced the disease status of their adjacent neighbors within areas circumscribed by at least 6 by 12 plants (larger quadrat size tested). The quadrat size modified values of parameters used to describe the spatial structure of epidemics. The index of dispersion increased whereas $\theta$ decreased with increasing quadrat size. Similar results were obtained for Sharka disease on peach (Prunus persica Miller) (Plum pox virus) (9) and Citrus tristeza virus on Citrus spp. (16). In both studies, the index of dispersion generally increased with increasing quadrat size, whereas $\theta$ changed little. A decrease in $\theta$ related to larger quadrat size reflects the averaging of local variation in incidence, which smoothes out interquadrat spatial variation detected at smaller quadrat size. Therefore, homogeneity within quadrats was higher for 2 by 4 plants per quadrat than for 6 by 12 plants per quadrat. Aggregation of disease incidence and the enlargement of primary foci over time also were indicated by semivariance analysis. The spatial dependency (A) ranged from 5.9 to $8.5 \mathrm{~m}$ in three of four experiments. It was particularly high $(15.2 \mathrm{~m}$ ) for plot P2 in 2004, but analyses could be skewed because of the coalescence of primary foci in this plot due to very high disease incidence (final assessment $0.61)$. The exponential model best fitted the data for all data sets.

TABLE 5. Results of amplified fragment length polymorphism analysis of strains of Xanthomonas axonopodis pv. allii isolated from bacterial blight of onion lesions in the experimental plots during 2 years

\begin{tabular}{lccccc}
\hline Plot & $\begin{array}{c}\text { Total no. of } \\
\text { diseased plants }\end{array}$ & No. of isolates & Inoculated strain $(\%)$ & Alternative haplotype (\%) & $\begin{array}{c}\text { No. of disease foci with } \\
\text { exogenous inoculum }\end{array}$ \\
\hline P1-2003 & 371 & 74 & $48(0.65)$ & $26(0.35)$ & 5 \\
P2-2003 & 281 & 46 & $41(0.89)$ & $5(0.11)$ & 7 \\
P1-2004 & 3,137 & 125 & $118(0.95)$ & $7(0.05)$ & 3 \\
P2-2004 & 4,293 & 133 & $121(0.91)$ & $12(0.09)$ & 2 \\
\hline
\end{tabular}

${ }^{a}$ Number of foci was determined as the number of onion plants bearing a haplotype of $X$. axonopodis pv. allii different of LMG 16528 and separated one from each other by distances larger than the range of spatial dependency calculated by geostatistical analysis of disease incidence data for the date under study.

TABLE 6. Contamination rates (CR) and percentages of positive samples of Xanthomonas axonopodis pv. allii detected from seed macerates from diseased and healthy samples collected in 2004

\begin{tabular}{|c|c|c|c|c|c|}
\hline \multirow[b]{2}{*}{ Plot } & \multirow[b]{2}{*}{ No. of seed samples } & \multicolumn{2}{|c|}{ Nested PCR detection ${ }^{\mathrm{a}}$} & \multicolumn{2}{|c|}{ Semiselective isolation ${ }^{\mathrm{a}}$} \\
\hline & & $\mathrm{CR}$ & Percent & $\mathrm{CR}$ & Percent \\
\hline \multicolumn{6}{|l|}{ P1-2004 } \\
\hline All samples & 405 & 0.00008 & 0.0198 & 0.00008 & 0.0198 \\
\hline Healthy samples from diseased quadrats & 190 & 0.00006 & 0.0140 & 0.00008 & 0.0186 \\
\hline Healthy quadrats & 25 & 0.00000 & $\ldots$ & 0.00000 & $\ldots$ \\
\hline$P$ & $\ldots$ & $\ldots$ & 0.727 & $\ldots$ & 1.000 \\
\hline Healthy samples from diseased quadrats & 205 & 0.00039 & 0.0905 & 0.00016 & 0.0381 \\
\hline Healthy quadrats & 5 & 0.00002 & 0.2000 & 0.00000 & \\
\hline$P^{\mathrm{b}}$ & $\ldots$ & $\ldots$ & 0.090 & $\ldots$ & 0.815 \\
\hline
\end{tabular}

a PCR = polymerase chain reaction. Semiselective isolations were performed on NCTM1 medium, as described by Roumagnac et al. (44).

${ }^{\text {b }} P$ values were obtained when the seed contamination rates in samples collected from diseased and asymptomatic plants were compared by an exact binomial test. 
The studied pathosystem was very different between the 2 years, probably due to the variation in weather conditions. The length of the incubation period on the inoculated plants was very different during the two studied years ( 24 to 37 days in 2003 versus 5 to 10 days in 2004). This difference can be explained by differences in temperatures prevailing at the time when the experiments were performed. In 2003, most daily mean temperatures during the month following inoculation were below $20^{\circ} \mathrm{C}$, a temperature threshold that previously was proposed for BBO progress (45). The observed length of the incubation period for the experiments performed in 2003 is in agreement with previous data published on $\mathrm{BBO}$ and other pathosystems associated with xanthomonads (27, $37,45,47$ ). In contrast, the warmer temperatures (mean $23^{\circ} \mathrm{C}$ ) prevailing at inoculation time in 2004 apparently led to an increased rate of development of lesions on inoculated plants. The number of hours with temperatures above $24^{\circ} \mathrm{C}$ during the latent infection period (28 in both years) was the best descriptor for predicting the number of DAI for BBO development on inoculated plants, consistent with previous studies $(45,50)$.

Seed contamination was detected at relatively similar rates both by a nested PCR assay and by the use of NCTM1 semiselective medium. This indicates that seedborne $X$. axonopodis pv. allii populations were composed, at least in part, of live cells. Seed contamination by $X$. axonopodis pv. allii was recorded at rates of $0.01(\mathrm{P} 1)$ and $0.05 \%(\mathrm{P} 2)$ only from plots with high disease incidence (2004, final incidence of 0.44 and 0.61 , respectively). Seed contamination rates obtained in the present study were similar to those reported previously from seed lots naturally contaminated by $X$. axonopodis pv. allii (44) and for other pathosystems involving xanthomonads (1). However, because bacteria can multiply and spread quickly under favorable conditions, very small rates of contaminated seed can constitute the source of primary inoculum for subsequent epidemics, as shown previously for $X$. axonopodis pv. allii (45). The importance of such epidemics often is exacerbated when crops are established from seedling transplants (1).

Our results confirm the general assumption that successful contamination of seed by a pathogenic bacterium occurs in a relatively small percentage of a population of seed (1). Seed contamination was detected only in plots with high disease incidence (year 2004). Furthermore, when seed contamination was detected, only the predominant bacterial haplotype on plants was detected from seed, as shown by AFLP analysis. A significant positive correlation was found between the incidence of $X$. axonopodis pv. phaseoli on bean (Phaseolus vulgaris L.) plants and seed contamination (58). A similar relationship was reported on the $X$. campestris pv. campestris on cabbage (Brassica oleracea L.) (48). Similarly, a correlation between levels of disease severity and resulting seed contamination rates was reported on wheat (Triticum aestivum L.) contaminated by $X$. translucens pv. translucens. Seed contamination was detected only on parent tillers with flag leaf severity $>15 \%$ (57). Although high levels of BBO incidence or severity were needed for detecting seed contamination, it should be emphasized that contaminated seed were detected from symptomless onion plants located near diseased plants at rates not significantly different from that estimated on seed lots originating from diseased plants. The detection of bean seed contaminated with $X$. axonopodis pv. phaseoli that originated from asymptomatic plants has been reported previously $(2,31)$.

Both inoculation of a traceable strain and systematic AFLP analysis of xanthomonads isolated from diseased plants were carried out in order to assess the biological significance of alternative sources of inoculum under our experimental conditions. A haplotype different from the inoculated strain was detected in all experimental plots. All strains collected in experimental plots that differed from the inoculated strain were identical and had the same AFLP fingerprint as strain CFBP 6369, which belongs to one of the two haplotypic groups of $X$. axonopodis pv. allii detected in Réunion and Mauritius Islands (42). The proportion of strains recovered from diseased plants that were genotyped by AFLP represented $18.4 \%$ of the total number of diseased plants in 2003 and $3.5 \%$ in 2004, due to high levels of disease incidence that year. However, all newly diseased plants which were separated from previously diseased plants by at least four (among rows) or eight (within rows) healthy plants and all newly diseased plants which were located at the edge of the plots were sampled and the corresponding Xanthomonas isolates were analyzed by AFLP. The design of this sampling scheme suggests that the estimation of the prevalence and composition of alternative inoculum sources is not strongly biased. Overall, the inoculated haplotype was isolated from $87 \%$ of the samples.

The exact origin of the detected alternative source or sources of inoculum remains speculative. There is no report, to our knowledge, of bulb lesions caused by $X$. axonopodis pv. allii and longterm survival of $X$. axonopodis pv. allii in or on onion bulbs. The detection of the CFBP6369-like haplotype in 2003 may have been related to wind-driven rains occurring on 8 or 12 August, with maximum rain intensity and wind speed of $10 \mathrm{~mm} \mathrm{~h}^{-1}$ and $9 \mathrm{~m} \mathrm{~s}^{-1}$ and $5 \mathrm{~mm} \mathrm{~h}^{-1}$ and $11 \mathrm{~m} \mathrm{~s}^{-1}$, respectively. In 2004, it may have been related to wind driven-rains occurring on 21 May, with maximum rain intensity and wind speed of $50 \mathrm{~mm} \mathrm{~h}^{-1}$ and $10 \mathrm{~m} \mathrm{~s}^{-1}$. Thus, detection of CFBP6369-like isolates in the plots always was preceded by episodes of wind-driven rains with wind speeds of $\geq 9 \mathrm{~m} \mathrm{~s}^{-1}$. Such events are uncommon on the experimental site (other than the occurrence of tropical storms, none of which occurred during the experiments); therefore, we hypothesize that this inoculum resulted from long-distance dispersal. Such wind speeds, associated with turbulence, allow movement of Xanthomonas cells over at least $10 \mathrm{~m}$ but probably more (5) and can cause water congestion of plant tissue, facilitating ingress of the pathogen $(17,51$, 52). Several inoculum sources of the pathogen (crop debris, temporary survival on weed or cultivated species, volunteer plants, and irrigation water) have been reported in Colorado $(13,14)$. No volunteer host plants were observed in our experiments. No weed species from which $X$. axonopodis pv. allii was detected in Colorado (13) was present within or in the vicinity of the experimental plots (data not shown); however, it is not known whether epiphytic $X$. axonopodis pv. allii was present on other weed species in the immediate vicinity of the experimental plots. Nevertheless, these recurrent occurrences of exogenous inoculum stress the need to monitor the genotype of the pathogen populations for an accurate assessment of the biological significance of the putative inoculum sources and for a sustainable control of this bacterial disease.

We successfully used AFLP analysis for identifying exogenous inoculum in epidemiological trials at a microgeographic scale. This technique has been used previously for phylogenetic analyses of xanthomonads $(24,25,38,43)$ and for evaluating the population structure of intrapathovar strain collections at different spatial scales (national, regional, and worldwide) $(6,26,28,40)$. Although widely used for studying the epidemiology of human bacterial pathogens $(11,20,34,39,53,59,60)$, the present study is, to our knowledge, the first contribution on the use of a genotyping method (AFLP and rep-PCR) for assessing the epidemiological significance of multiple inoculum sources on a pathosystem involving a plant-pathogenic bacterium. Our results suggest that this approach may be helpful in the future for an improved understanding of the epidemiology of $X$. axonopodis pv. allii $(13,14,44,45)$ and other xanthomonads for which large genetic diversity has been reported $(28,29,40)$.

\section{ACKNOWLEDGMENTS}

Odéadom, the European Union (FEOGA), Conseil Général de La Réunion and CIRAD provided financial support. We thank C. Vernière, T. Gottwald, J. Veslot, and J. Chadoeuf for helpful discussion; and A. Couteau, W. Grondin, C. Hoareau, J. Degas, C. Boyer, and J. J. Cheron for technical assistance. 


\section{LITERATURE CITED}

1. Agarwal, V. K., and Sinclair, J. B. 1997. Principles of Seed Pathology, 2nd ed. CRC Lewis, Boca Raton, FL.

2. Aggour, A. R., Coyne, D. P., Vidaver, A. K., and Eskridge, K. M. 1989. Transmission of the common blight pathogen in bean seed. J. Am. Soc. Hortic. Sci. 114:1002-1008.

3. Alvarez, A. M., Buddenhagen, I. W., Buddenhagen, E. S., and Domen, H. Y. 1978. Bacterial blight of onion, a new disease caused by Xanthomonas sp. Phytopathology 68:1132-1136.

4. Audy, P., Braat, C. E., Saindon, G., Huang, H. C., and Laroche, A. 1996. A rapid and sensitive PCR-based assay for concurrent detection of bacteria causing common and halo blights in bean seed. Phytopathology 86:361-366.

5. Bock, C. H., Parker, P. E., and Gottwald, T. R. 2005. Effect of simulated wind-driven rain on duration and distance of dispersal of Xanthomonas axonopodis pv. citri from canker-infected citrus trees. Plant Dis. 89:71-80.

6. Boudon, S., Manceau, C., and Notteghem, J. L. 2005. Structure and origin of Xanthomonas arboricola pv. pruni populations causing bacterial spot of stone fruit trees in Western Europe. Phytopathology 95:1081-1088.

7. Campbell, C. L., and Madden, L. V. 1990. Temporal analysis of epidemics. I: Description and comparison of disease progress curves. Pages 161-202 in: Introduction to Plant Disease Epidemiology. John Wiley \& Sons, New York.

8. Cochran, W. G. 1977. Sampling Techniques, 3rd ed. John Wiley \& Sons, New York.

9. Dallot, S., Gottwald, T., Labonne, G., and Quiot, J. B. 2003. Spatial pattern analysis of sharka disease (Plum pox virus strain M) in peach orchards of southern France. Phytopathology 93:1543-1552.

10. Davidian, M., and Giltinan, D. M. 1995. Nonlinear models for repeated measurement data. In: Monographs on Statistics and Applied Probability, Vol. 62. Chapman \& Hall/CRC Press, Boca Raton, FL.

11. Duim, B., Godschalk, P. C. R., Van den Braak, N., Dingle, K. E., Dijkstra, J. R., Leyde, E., Van der Plas, J., Colles, F. M., Endtz, H. P., Wagenaar, J. A., Maiden, M. C. J., and Van Belkum, A. 2003. Molecular evidence for dissemination of unique Campylobacter jejuni clones in Curacao, Netherlands Antilles. J. Clin. Microbiol. 41:5593-5597.

12. Gent, D. H., Al-Saadi, A., Gabriel, D. W., Louws, F. J., Ishimaru, C. A., and Schwartz, H. F. 2005. Pathogenic and genetic relatedness among Xanthomonas axonopodis pv. allii and other pathovars of $X$. axonopodis. Phytopathology 95:918-925.

13. Gent, D. H., Lang, J. M., Bartolo, M. E., and Schwartz, H. R. 2005. Inoculum sources and survival of Xanthomonas axonopodis pv. allii in Colorado. Plant Dis. 89:507-514.

14. Gent, D. H., Lang, J. M., and Schwartz, H. F. 2005. Epiphytic survival of Xanthomonas axonopodis pv. allii and $X$. axonopodis pv. phaseoli on leguminous hosts and onion. Plant Dis. 89:558-564.

15. Gent, D. H., Schwartz, H. F., Ishimaru, C. A., Louws, F. J., Cramer, R. A., and Lawrence, C. B. 2004. Polyphasic characterization of Xanthomonas strains from onion. Phytopathology 94:184-195.

16. Gottwald, T. R., Cambra, M., Moreno, P., Camarasa, E., and Piquer, J. 1996. Spatial and temporal analysis of citrus tristeza virus in Eastern Spain. Phytopathology 86:45-55.

17. Gottwald, T. R., Graham, J. H., and Schubert, T. S. 2002. Citrus canker: The pathogen and its impact. Online. Plant Health Progress doi: 10.1094/PHP-2002-0812-01-RV.

18. Gottwald, T. R., Sun, X., Riley, T., Graham, J. H., Ferrandino, F., and Taylor, E. L. 2002. Geo-referenced spatiotemporal analysis of the urban citrus canker epidemic in Florida. Phytopathology 92:361-377.

19. Greig-Smith, P. 1952. The use of random and contiguous quadrats in the study of the structures of plants communities. Ann. Bot. 16:293-316.

20. Huang, B., Heron, B. A., Gray, B. R., Eglezos, S., Bates, J. R., and Savill, J. 2004. A predominant and virulent Legionella pneumophila serogroup 1 strain detected in isolates from patients and water in Queensland, Australia, by an amplified fragment length polymorphism protocol and virulence gene-based PCR assays. J. Clin. Microbiol. 42:4164-4168.

21. Huet, S., Bouvier, A., Gruet, M. A., and Jolivet, E. 1996. Statistical Tools for Nonlinear Regression, Springer Series in Statistics. Springer-Verlag, New York.

22. Hughes, G., and Madden, L. V. 1992. Aggregation and incidence of disease. Plant Pathol. 41:657-660.

23. Hughes, G., and Madden, L. V. 1993. Using the beta-binomial distribution to describe aggregated patterns of disease incidence. Phytopathology 83:759-763.

24. Janse, J. D., Rossi, M. P., Gorkink, R. F. J., Derks, J. H. J., Swings, J., Janssens, D., and Scortichini, M. 2001. Bacterial leaf blight of strawberry (Fragaria (X) ananassa) caused by a pathovar of Xanthomonas arboricola, not similar to Xanthomonas fragariae Kennedy \& King. Description of the causal organism as Xanthomonas arboricola pv. fragariae (pv. nov., comb. nov.). Plant Pathol. 50:653-665.
25. Janssen, P., Coopman, R., Huys, G., Swings, J., Bleeker, M., Vos, P., Zabeau, M., and Kersters, K. 1996. Evaluation of the DNA fingerprinting method AFLP as a new tool in bacterial taxonomy. Microbiology (Read.) 142:1881-1893.

26. Khodakaramian, G., and Swings, J. 2002. AFLP fingerprinting of the strains of Xanthomonas axonopodis inducing citrus canker disease in southern Iran. J. Phytopathol. 150:227-231.

27. Koizumi, M. 1976. Incubation period of citrus canker in relation to temperature. Bull. Fruit Tree Res. Stn. Jpn. B 3:33-46.

28. Loreti, S., Gallelli, A., Belisario, A., Wajnberg, E., and Corazza, L. 2001. Investigation of genomic variability of Xanthomonas arboricola pv. juglandis by AFLP analysis. Eur. J. Plant Pathol. 107:583-591.

29. Louws, F. J., Rademaker, J. L. W., and De Bruijn, F. J. 1999. The three Ds of PCR-based genomic analysis of phytobacteria: Diversity, detection, and disease diagnosis. Annu. Rev. Phytopathol. 37:81-125.

30. Ludwig, J. A. 1979. A test of different quadrat variance methods for the analysis of spatial pattern. Pages 289-304 in: Spatial and Temporal Analysis in Ecology. R. M. Cormack and J. K. Ord, eds. Int. Coop. Publ. House, Fairland, MD.

31. Mabagala, R. B. 1997. The effect of populations of Xanthomonas campestris pv. phaseoli in bean reproductive tissues on seed infection of resistant and susceptible bean genotypes. Eur. J. Plant Pathol. 103:175181.

32. Madden, L. V., and Hughes, G. 1994. BBD-computer software for fitting the beta-binomial distribution to disease incidence data. Plant Dis. 78:536-540.

33. Masmoudi, K., Duby, C., Suhas, M., Guo, J. Q., Taylor, J. D., and Maury, Y. 1994. Quality control of pea seed for pea seed-borne mosaic virus. Seed Sci. Technol. 22:407-414.

34. Motiwala, A. S., Strother, M., Amonsin, A., Byrum, B., Naser, S. A., Stabel, J. R., Shulaw, W. P., Bannantine, J. P., Kapur, V., and Sreevatsan, S. 2003. Molecular epidemiology of Mycobacterium avium subsp. paratuberculosis: evidence for limited strain diversity, strain sharing, and identification of unique targets for diagnosis. J. Clin. Microbiol. 41:20152026.

35. Nunez, J. J., Gilbertson, R. L., Meng, X., and Davis, R. M. 2002. First report of Xanthomonas leaf blight of onion in California. Plant Dis. 86:330.

36. Paulraj, L., and O'Garro, L. W. 1993. Leaf blight of onions in Barbados caused by Xanthomonas campestris. Plant Dis. 77:198-201.

37. Pruvost, O., Gottwald, T. R., and Brocherieux, C. 1999. The effect of irrigation practices on the spatio-temporal increase of Asiatic citrus canker in simulated nursery plots in Réunion Island. Eur. J. Plant Pathol. 105:23-37.

38. Rademaker, J. L. W., Hoste, B., Louws, F. J., Kersters, K., Swings, J., Vauterin, L., Vauterin, P., and De Bruijn, F. J. 2000. Comparison of AFLP and rep-PCR genomic fingerprinting with DNA-DNA homology studies: Xanthomonas as a model system. Int. J. Syst. Evol. Microbiol. 50:665-677.

39. Reche, M. P., Echeita, M. A., Garcia de los Rios, J. E., Usera, M. A., Jimenez, P. A., Rojas, A. M., Colas, J., and Rodriguez, I. 2003. Comparison of phenotypic and genotypic markers for characterization of an outbreak of Salmonella serotype Havana in captive raptors. J. Appl. Microbiol. 94:65-72.

40. Restrepo, S., Duque, M., Tohme, J., and Verdier, V. 1999. AFLP fingerprinting: An efficient technique for detecting genetic variation of Xanthomonas axonopodis pv. manihotis. Microbiology (Read.) 145:107-114.

41. Robene-Soustrade, I., Roumagnac, P., Couteau, A., and Pruvost, O. 2004. Elaboration d'un outil de détection de Xanthomonas axonopodis pv. allii, agent de la bactériose de l'oignon. Paper read at 6èmes Rencontres Plantes Bactéries, Aussois, France.

42. Roumagnac, P. 2003. Taxonomie et diversité du Xanthomonas responsable du dépérissement bactérien de l'oignon. Etudes épidémiologiques du rôle des semences dans la transmission de la bactérie. Ph.D. thesis, INA P-G, Paris.

43. Roumagnac, P., Gagnevin, L., Gardan, L., Sutra, L., Manceau, C., Dickstein, E. R., Jones, J. B., Rott, P., and Pruvost, O. 2004. Polyphasic characterization of xanthomonads isolated from onion, garlic and Welsh onion (Allium spp.) and their relatedness to different Xanthomonas species. Int. J. Syst. Evol. Microbiol. 54:15-24.

44. Roumagnac, P., Gagnevin, L., and Pruvost, O. 2000. Detection of Xanthomonas sp., the causal agent of onion bacterial blight, in onion seeds using a newly developed semi-selective isolation medium. Eur. J. Plant Pathol. 106:867-877.

45. Roumagnac, P., Pruvost, O., Chiroleu, F., and Hughes, G. 2004. Spatial and temporal analyses of bacterial blight of onion caused by Xanthomonas axonopodis pv. allii. Phytopathology 94:138-146.

46. Savary, S., Castilla, N. P., and Willocquet, L. 2001. Analysis of the spatiotemporal structure of rice sheath blight epidemics in a farmer's field. Plant Pathol. 50:53-68.

47. Schaad, N. W. 1982. Detection of seedborne bacterial plant pathogens. Plant Dis. 66:885-890 
48. Schaad, N. W., Sitterly, W. R., and Humaydan, H. 1980. Relationship of incidence of seedborne Xanthomonas campestris to black rot of crucifers. Plant Dis. 64:91-92.

49. Schwartz, H. F., and Otto, K. 2000. First report of leaf blight of onion caused by Xanthomonas campestris in Colorado. Plant Dis. 84:922.

50. Schwartz, H. F., Otto, K. L., and Gent, D. H. 2003. Relation of temperature and rainfall to development of Xanthomonas and Pantoea leaf blights of onion in Colorado. Plant Dis. 87:11-14.

51. Serizawa, S., and Inoue, K. 1975. Studies on citrus canker. III. The influence of wind on infection. Bull. Shizuoka Citrus Exp. Stn. 11:54-67.

52. Serizawa, S., Inoue, K., and Goto, M. 1969. Studies on citrus canker disease. I. Dispersal of the citrus canker organism. Bull. Fac. Agric. Shizuoka Univ. 8:81-85.

53. Spence, R. P., Van der Reijden, T. J. K., Dijkshoorn, L., and Towner, K. J. 2004. Comparison of Acinetobacter baumannii isolates from United Kingdom hospitals with predominant Northern European genotypes by amplified-fragment length polymorphism analysis. J. Clin. Microbiol. 42:832-834.

54. Stall, R. E., Gottwald, T. R., Koizumi, M., and Schaad, N. C. 1993. Ecology of plant pathogenic xanthomonads. Pages 265-299 in: Xanthomonas. J. G. Swings and E. L. Civerolo, eds. Chapman \& Hall, London.
55. Taylor, L. R. 1961. Aggregation, variance and the mean. Nature 189:732735 .

56. Tubajika, K. M., Civerolo, E. L., Ciomperlik, M. A., Luvisi, D. A., and Hashim, J. M. 2004. Analysis of the spatial patterns of Pierce's disease incidence on the lower San Joaquin valley in California. Phytopathology 94:1136-1144.

57. Tubajika, K. M., Tillman, B. L., Russin, J. S., and Harrison, S. A. 1998. Relationship between flag leaf symptoms caused by Xanthomonas translucens pv. translucens and subsequent seed transmission in wheat. Plant Dis. 82:1341-1344.

58. Valarini, P. J., Menten, J. O. M., and Lollato, M. A. 1992. Incidência do crestamento bacteriano comum no campo e transporte de Xanthomonas campestris pv. phaseoli pela sementes de feijão, obtidas por diferentes métodos. Summa Phytopathol. 18:160-166.

59. Vijayachari, P., Ahmed, N., Sugunan, A. P., Ghousunnissa, S., Rao, K. R., Hasnain, S. E., and Sehgal, S. C. 2004. Use of fluorescent amplified fragment length polymorphism for molecular epidemiology of leptospirosis in India. J. Clin. Microbiol. 42:3575-3580.

60. Vogel, B. F., Huss, H. H., Ojeniyi, B., Ahrens, P., and Gram, L. 2001. Elucidation of Listeria monocytogenes contamination routes in coldsmoked salmon processing plants detected by DNA-based typing methods. Appl. Environ. Microbiol. 67:2586-2595. 